therefore added a snake-house so that it can send regular supplies of venom to Paris; and it has, in fact, become the French African centre for research on snakes. The Institute also acts as a depot for the supply of anthropoid apes to France and sends to the Institut Pasteur of Paris some two hundred a year.

The Council of Administration of the Institut Pasteur of Paris has recently decided to strengthen the Kindia Institute, to enable it to resume its prewar activities. The staff now consists of a medical director, assisted by a veterinary surgeon and a team of technical assistants. The director, Colonel Lefrou, is very anxious to be kept informed of research in Great Britain in the fields in which he is particularly interested-anthropology, biology and zoology-and would be glad to receive scientific literature. $\mathrm{He}$ would send in return reprints of the Institute's reports, which will appear, as. in the past, in the Bulletin de la Société de Pathologie Exotique or in the Annales de l'Institut Pasteur. He would also welcome any inquiries from British research workers who are interested in the Institute's activities, to be addressed to : Le Médecin Colonel Lefrou, Directeur de l'Institut Pasteur, Kindia, Guinée Française.<smiles>CC(C)(C)O</smiles>

\section{MARINE BIOLOGY IN BRITAIN}

$\mathrm{T}$ HE annual reports* of three British marine biological laboratories have recently been published. In geh the period under review has been one of plost-war re-organisation and expanding actifity.

Afe report of the Millport Laboratory of the Scottish Marine Biological Association appears in a larger format than formerly, and is bound inside a common cover, with copies of all scientific papers published from the Laboratory in the course of the year. These 'collected reprints' will not only form a useful exchange for the publications of other laboratories, but will also, for the first time, provide an adequate indication of the scope of the work carried out at Millport.

The Laboratory's 40-ft. vessel Nautilus, which has given such good service since 1923 and is well known to many biologists, has now been replaced by a new and larger ship-a 75-ft. Admiralty-built motor fishing vessel which has been extensively altered and refitted to adapt her for scientific research work. Her name, fittingly enough, is Calanus, after a small planktonic crustacean, important as fish food, on which much productive research has been done at Millport. A photograph of the Calanus and her predecessor, the Nautilus, forms a frontispiece to the report.

During the year covered by the report, the staff was enlarged by the appointment of an algologist and an additional zoologist, and Dr. A. P. Orr, a senior member, was made deputy director on assuming special responsibilities in respect of the new and larger ship. The scientific work of the station, in full swing on an increased scale, covered plankton investigations, oyster culture, life-histories and growth-rates

* The Scottish Marine Biological Association: Report of the Executive to the Council for the year to March 31, 1948. Pp. 36.

(Marine Station, Keppel Pier, Millport, Isle of Cumbrae.) n.p. The Marine Biological Station, Port Erin, Isle of Man: Annua Report (No. 61) for 1948. (University Press of Liverpool, June 1949.) $3 s$ for the Year ending July 31, 1947. (Newcastle upon Tyne: Marine Laboratory Committee of King's College, 1949.) 58 . of marine algæ, anti-fouling researches, structure and habits of molluses, and general faunistic observations.

The Port Erin Laboratory, Isle of Man, likewise reports additions to its staft and increasing activity on a wider scientific front made possible by the acquisition of a motor research vessel, a $61 \frac{1}{2}$-ft. Admiralty motor fishing vessel suitably converted, and christened the William Herdman. She is equipped for seine-netting in addition to trawling and is fitted. with an outboard type of echo-sounder. Immediately the ship became available, in September 1948, biological investigations at sea were put in hand, particular efforts being made to discover and survey herring spawning grounds. Plankton studies and researches into the life-histories of marine animals and plants are also being carried out.

At the Dove Marine Laboratory, Cullercoats, research is also proceeding actively. All members of the staff have taken part in an important survey of the marine fauna of the district, an ambitious programme of which much yet remains to be done, especially below low-water mark. In addition, an intensive study of salmon in the fishery district of the River Tyne has been completed, and an investigation into the physico-chemical conditions in estuarine muds, with special reference to the evolution and absorption of phosphates, has been begun.

After reading these reports, one is left in no doubt that marine biological research in Great Britain, after the relative stagnation of war-time, is now restored to full and vigorously growing activity. This is most welcome news, for there is, indeed, much to do in every branch of the subject.

G. A. Steven

\section{FOURTEENTH INTERNATIONAL VETERINARY CONGRESS}

TORE than a thousand delegates and members 1 from fifty-tbree countries attended the recent International $\mathrm{Xe}$ erinary Congress held in London. The theme hue Congress was the contribution of the retinary profession to world food supplies, and Los Boyd Orr Apressed the view that "if the control bf animg dfoases could be organised on a worldwide basis, tifere is no doubt that with our present knowledge we could enormously increase the amount of dairy and meat products available for human consumption". He went on to say : "Here then is a great field for veterinary science. Unfortunately, like all other branches of biological science which seek to enrich the world in the equal interest of the people of all countries, it is starved of funds. The veterinary profession needs a strong international organisation on the lines of the World Health Organisation, through which Governments could co-operate more actively in the elimination of preventable diseases on a world scale."

Both the lectures delivered in plenary session and the papers presented at the thirty-one sectional meetings were largely concerned with veterinary preventive medicine. There was considerable emphasis upon measures for improving the health of whole herds and for controlling disease upon the widest scale, national and international-a fact which must have impressed any layman who still thought of the veterinary surgeon as someone who merely treats the individual animal after it has become ill or injured. 